\title{
Studies on the Estrogen Metabolism in the Patients with Amenorrhea
}

\section{Masahiko KUSUDA, Ritsuo SHIGYO, Arihiro KUMAMOTO and Yasumasa NOTOMI}

\author{
Department of Obstetrics and Gynecology (Director : Prof. K. KOGA) \\ Faculty of Medicine, Kyushu University
}

The patients with primary and secondary amenorrhea were endocrinologically examined, using the determination of urinary estrogens, 17-KS, PBI, BBT and several other tests. In 17 amenorrheic women there were slight differences in the amounts of PBI and 17-KS, although the estrogen excretions were somewhat different: in the primary amenorrhea $10.5 \pm 2.7 \mu \mathrm{g} /$ day (mean of five cases), the secondary amenorrhea $16.1 \pm 4.2 \mu \mathrm{g} /$ day (mean of twelve cases), the follicular phase of normal cycle $23.8 \pm 4.6$ $\mu \mathrm{g} /$ day (mean of seven cases) and the luteal phase of normal cycle $46.2 \pm 8.9 \mu \mathrm{g} / \mathrm{day}$ (mean of seven cases).

Five cases were selected in our clinic among the patients suffering from functional amenorrhea. Estrogen was administered as a single injection of $2 \mathrm{mg}$. of estradiol benzoate, and after two or three weeks, Pregnant Mare Serum Gonadotrophin (PMS) 7,000-22,000 IU and Human Chorionic Gonadotrophin (HCG) 6,000 IU-9,000 IU were administered to induce the ovulation.

The urinary excretion of estrogens was determined as serially as possible by Brown's method which was slightly improved in chromatography.

The maximal output values of the classical estrogens occurred on the third or the fourth day after the injection and the individual variation of estrogen excretion pattern was observed:

In two cases (case 1,2) the ratio of estrone + estradiol/total estrogens was decreased in a few days after the administration of estradiol benzoate. From these results it is presumed that the conversion of estrogens in vivo from estradiol to estriol went on smoothly. In addition, in these cases the ovulation was induced by the administration of PMS and HCG and the urinary estrogens were remarkably increased, to such amounts as three or four fold more than the values in normal ovulatory phase. On the other hand, in one case (case 3) the ratio remained at a comparatively high level for several days after the administration of estrogen; ovulation could not be induced and the urinary estrogens were in low levels. In this case the ovaries were atrophic and only primary follicles were observed histologically.

In two cases of secondary amenorrhea with hyperthyroidism (case 4,5), the patterns of urinary estrogens were varied. That is, in one case (case 4) the estrogen metabolism was presumed to be normal, and in the other case (case 5), however, the estrogen metabolism was bad, and after 10 days' administration of Methylthiouracil the 
estrogen was again administered in the same way as above mentioned, and the estrogen metabolism changed from bad into normal.

Further studies on those problems are necessary, however, and it is also reasonable to consider that the estradiol tolerance test is one of the valuable methods in research on ovarian dysfunction. (pp. 974 977) 


\section{無月経婦人の Estrogen 代謝に関する研究}

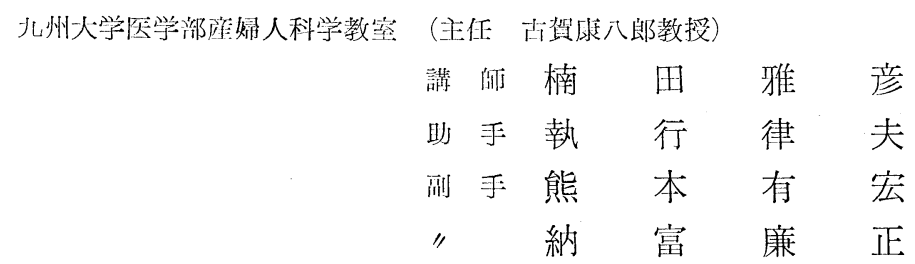

(畞和39年 7 月 4 日受付)

ま えがき

無月経婦人の諸種ホルモンの代謝や各内分泌腺相互間の関係を知るととは，治療の実際に当つて大きな助 けとなるものである，我々はこの問題を解明し，治療成績の向上を計る一端として，まず estrogen（以下 Est. と略す）および gonadotrophin 負荷後の尿中 Est. 排泄量の動態を中心として検討を進めているので, 現在までに得た知見について報告したい.

\section{実験材料ならびに方法}

対象とした婦人は九大産婦人科不妊症外来において検査，治療を行なつている患者の中より適宜に選択し た. 内訳は原発性無月経（I 度） 1 例，続発性無月経 4 例（I 度 3 例，II度 1 例）の計 5 例である。いずれ も 4 ヶ月以上の基礎体温 (BBT) 観察, 内膜組織検查によつて無排卵であるととを磪認し, gestagen-test

(以下 G-test と略す) によつて無月経の程度を定めた。尿中 Est. の分画測定は Brown 法に準拠し, chromatography に改変を加えた既報》の方法を用い，そのほかPBI 测定，17-KS 测定を併せ行なつた。 estradiol benzoate $2 \mathrm{mg}$ を筋肉内に注射し, その前後に亘つて可及的 serial に尿中 Est. 測定を行なつた. さらに $2 \sim 3$ 週間後から PMS, HCG 投与による排卵誘発法を施行し，その間は Est. 排泄量測定のほかに 頸管粘液の量, 索絲性, 結晶形成の程度や BBT, 内膜バイオプシーによつて排卵の有無を検索した。

\section{実 験 成 績}

まず対照とした健康成熟婦人の尿中 Est. 排泄量は卵胞期 $23.8 \pm 4.6 \mu \mathrm{g} / \mathrm{day}$, 黄体期 $46.2 \pm 8.9 \mu \mathrm{g} /$ day (各 7 例の平均) であつたのに対して，原発性無月経では $10.5 \pm 2.7 \mu \mathrm{g} / \mathrm{day}$ ( 5 例の平均), 続発性無月経 $16.1 \pm$ $4.2 \mu \mathrm{g} / \mathrm{day}$ (10例の平均) であつた. 個々の排泄量 は各群別に明膫な差がある訳ではなく, 症例別には かなりの変動か認められた。しかし平均值からみる と Est. 排泄量は黄体期 $>$ 卵胞期 $>$ 続発性無月 経> 原発性無月経の順に低下しているととが確認された。 estradiol benzoate (以下 Ed-benz. と略す) 負 街前後, および gonadotrophin 負荷時の尿中 Est. 量の pattern はFig. 1 4 亿示す如くであつた。

症例 1 （Fig. 1) は無月経期間約 2 年間の続発性 無月経で G-test によつて無月経 I 度と判明したも のである. BBT は低温 1 相性を続け, Est. も15 $\mu$ g.l day と低值であつたが甲状腺, 副腎皮質機能には異 常を認めなかつた．Ed-benz. 負荷後の排泄 pattern

Fig. 1. Urinary excretion of estrogens after administration of estradiol benzoate and PMS, HCG

No. 1 H.N. 25yrs. Sec. Am. PBI $4.5 \gamma /$ dl. $17-\mathrm{KS} 3.6 \mathrm{mg}$./day

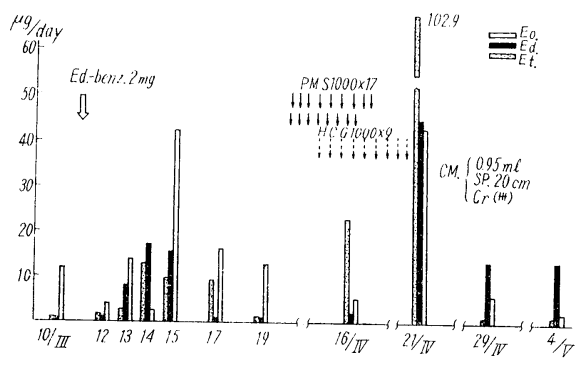


をみると, estrone (Eo) estradiol-17ß (Ed), estriol (Et) の3 分画ともに増加したが, 特に Et 分画の増加 が著明で生体内における Edから Etへの conversion はほぼ円滑に進行したものと推定された。さらに PMS 1,000 I.U. × 17, HCG 1,000 I.U.×7 の投与によつて頸管粘液（G.M）の量は $0.95 \mathrm{ml}$, 率絲性 (Sp.) $20 \mathrm{~cm}$, 結晶形成 (Cr.) は(H) となり，ついで BBT は急上昇して，11日間の高温相を持続し，内膜組織像 は分泌像を示し,つづいて月経様出血の発来を認め, 明らが排卵を誘発し得たてとを確認した. gonadotrophin 投与終了直後の Est. は総量 $189.7 \mu \mathrm{g}$./day の大量を示したが，乙れは正常婦人排卵期の 60〜80 $\mu \mathrm{g}$./day の量に較べ遙かに多い量である.

症例 2 は無月経期間 8 カ月の I 度無月経の症例で， BBT は低温 1 相性，Est. 活性は低いが，甲状腺機能， 副腎皮質機能には異常は認めなかつた。 Ed-beng. 負荷後の. Est. 排泄 pattern は症例 1 と酷似し, Et 分画 の增加が明らかに認められた. 本例も引続いて施行した PMS 1,000 I.U. × 15, HCG 1,000 I.U.×7 の投与で, $\mathrm{CM}$ は $0.6 \mathrm{ml}, \mathrm{Sp} .13 \mathrm{~cm}, \mathrm{Cr}$. (卅) と好転し, 尿中 Est. は総量 $242.3 \mu \mathrm{g} . / \mathrm{day}$ の高值を示し, gonadotrophin 投与終了後 6 日目より中等量の消褪出血発来を認めた.

以上の症例 1，2 2 Est. 負荷, gonadotrophin 負荷に対して臨床経過においても, 尿中 Est. 排泄 pattern でも同様な反応を示したものである.

Fig. 2. Urinary excretion of estrogens after administration of estradiol benzoate and PMS, HCG

No. 3 S.N. 25yrs. Prim. Am. PBI 4.0 $/ \mathrm{dl}$. $17-\mathrm{KS} 6.0 \mathrm{mg} . / \mathrm{day}$

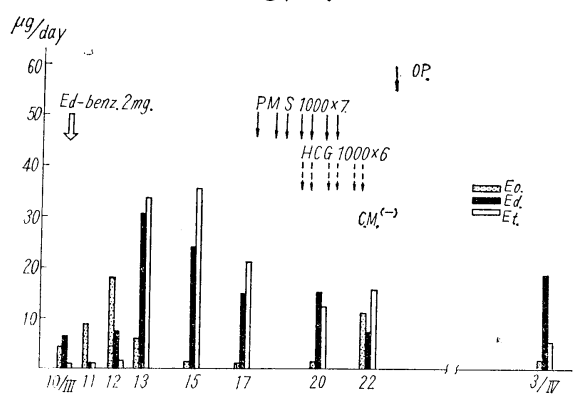

謝，すなわちEdより Etへの conversion が円滑に 進行するものは PMS や HCG 等の gonadotrophin に対する卵巣の反応性も比較良好である。乙れに対 して Est. 代謝に阻害が推定される例では godadotrophin に対しても卵巣は反応し難いようである. すなわち卵巣の機能と Est. 代謝, 換言すると Est. 代謝と gonadotrophin 感受性と密接な関係䎲ある ものと思われ，またてのととは無月経の程度，期間 や卵巣の組織学的〜肉眼的所見と照合して矛盾は感 ビられない.

症例 4（Fig. 3) は無月経期間 4 年間の続発性無 月経第 1 度の患者で副腎皮質機能には異常は認めら れないが PBI 10.2 $/ \mathrm{dl}, \mathrm{BMR}+35 \%$ を示し甲状腺 機能充進が推定された症例である。 Ed-benz. 投与 後の尿中 Est. の pattern からはEtへの conversion は症例 1，2 とほほ同様に円滑に進行しているょう
症例 3 (Fig. 2) は25才の原発性無月経で, Est. 活性が極めて低く II度無月経である. Ed-benz. 負荷後は概して Et の增加が少なく, てれに反して $\mathrm{Ed}$ 分画の排泄遅延が印象的である。すなわち $\mathrm{Ed}$ より Etへの conversion に阻害があるととが推定 される. 本例に図の如く, PMS 1,000 I.U. ×7, HCG 1,000 I.U. $\times 6$ の投与を行なつたが G.M の 状態は全く好転の傾向がなく, BBTも低温を持続 し, 消祓出血も発来せず, 尿中 Est. はほとんど增 加の傾向を示していない. 本例は試験開腹によつて 卵巣発育不全を認め, その組織像も原始卵胞のみで 発育〜成熟卵胞の無い極めて未熟なものであつた。

小括 以上の成績からみると Ed-benz. 負荷後の 尿中 Est. 各分画の変動状態から推定した Est. 代

Fig. 3. Urinary excretion of estrogens after administration of estradiol benzoate and PMS, HCG

No. 4 S.F. 28yrs. Sec. Am. PBI 10.2 $/$ dl. B.M.R. $+35 \%$ 17-KS $4.2 \mathrm{mg} . /$ day

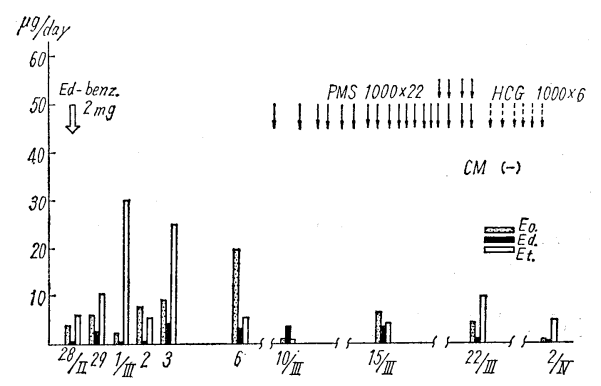


に思われたが，引続いて行なつた gonadotrophin 負荷には全く反応しなかつた。

Fig. 4. Urinaly excretion of estrogens after administration of estradiol benzoate and double injection during the Methiocil treatment

No. 5 Y.M. 23yrs. Sec. Am. PBI 10.2 $/$ dl. 17-KS 2.8mg./day

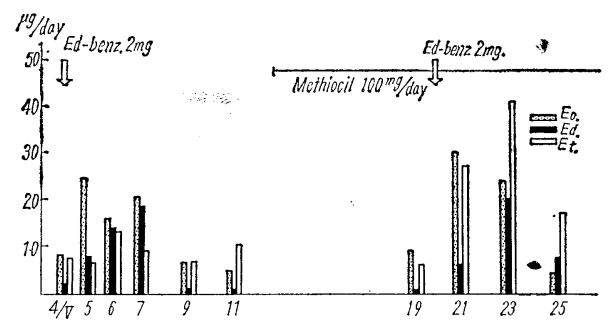

症例 5 (Fig. 4) は続発性無月経 2 年間，I 度の 婦人で，17-KS はやや低值であつたが正常範罒で あつた. Ed-benz. 負荷後の Est. 排泄 pattern か らは conversion 不良の成績を得た。本例は明状腺 機能无進があつたので Methiocil 100mg/day を 30日間投与した，その途中で再び Ed-benz. 負荷 を行なつたところ，Et分画の上昇が著明で Eo $+\mathrm{Ed} /$ total が低い，いわゆる good conversion の pattern を得た。

小括 症例 $4 ， 5$ はいずれも甲状腺機能穴進を伴 つた無月経婦人であるが，負荷試験の成績は必ずし も一元的に解釈し得るような結果は示していない. すなわち症例 4 では甲状腺機能元進のために見せか

けの正常 Est. 代謝の像を示したものとも解せられるが，症例 5 では全く反対の pattern を示しており，甲 状腺機能立進すなわち Est. 代謝六進とは断定出来ないようであり，また抗甲状腺剤である Methiocil の投 与で Est. 代謝が好転した事実もその裏づけとなるように思われる．乙の問題の解決にはより多くの症例に ついて詳細な分析や，甲状腺機能立進の実態，Methylthiouracil の作用機序などを考虑して慎重に検討 すべき問題であろう.

\section{まとめ}

以上少数例ではあるが種々の機能性無月経婦人に Ed-benz. および PMS, HCG による Gonadotrophin 負荷を行ない，その前後における尿中 Est. 排泄量の推移を中心として考察を試みた. すなわち卵巣機能障 害が軽度な場合は Ed より Etへの conversion も円滑に進行し，てのような例では卵巣の gonadotrophin 感受性も高い，乙れに対して卵巣機能障害が高度なものでは Est 代謝も悪く, gonadotrophin 感受性も悪い ように思われた。

我々はさきに正常婦人に Ed-benz，を負荷した場合は Ed から Etへの転換が速かで Et 分画が著増し，Eo $+\mathrm{Ed} /$ total が速かに低下する傾向がみられるのに対し，去勢婦人では Et 分画の増加がでく軽度で，Eo+ Ed/total はかなり高值を持続し，Est 代謝に何らかの阻害があるととを認めている ${ }^{2)}$. とれに今回の成績 を併せ考えると Est代謝には卵巣の有無が大きく関与し，さらに卵单の機能が関係していると推定せざるを 得ない. この卵巣機能を具体的に表現するととは現段階においてはなお困難であるが，おそらく卵巣内に存 在する 16-Hydroxylase その他の酵素系の活性やその生産に由来するものであろうと考える。乙れら酵素の 活性と卵巣の gonadotrophin 感受性との関係も今後の重要問題であろう。また PMS に続いて HCG 投与して排卵を誘発した際の尿中 Est. 量が，正常排卵期の数倍の高值を示し，しかも Eo, Ed 分画が比較 的優位であることはこれら gonadotrophin の刺㦸による排卵の機転や Est. 産生が自然排卵とはかなり異な つた代謝過程で行なわれているととを示すものではないかと思う。 そのほか, 甲状腺機能と Est. 代謝につい てはなお推定も為し難い段階であるが，従来諸家の報告 ${ }^{324) 5}$ にみられる如く一元的なものではないようであ り, 今後症例を重ねることによつて興味ある知見が得られるであろう。いずれにせよ，とのような estrogen や gonadotrophin の負荷試験は今後の無月経ないし卵巣機能異常の病態生理の分析や研究法として 有意義 なものであると思う。

（本論文は第37回日本内分泌学会総会に打いて発表した） 


\section{主 要 文 献}

1) M. KUSUDA., R. SHIGYO and A. KUMAMOTO : Folia Endocrinologica Japonica., 39 : 637, (1963). 2 2) R. SHIGYO : in press

3 ) S. TIMONEN u. E. HIROVONEN :

Geburtsh. u. Frauenhk., 22 : 948, (1962).

4) S. TIMONEN., C.J. JOHANSON and E.

HIRVONEN : Acta endocrinol., 39 : 491, (1962).

5) E. DICZFALUSY, u. C. LAURITZEN :

Oestrogene beim Menschen : Springer, Berlin, (1961). 